TITLE:

\title{
Thermodynamics of the $\mathrm{O} / \mathrm{O}^{2}$ redox couple in molten ( $\mathrm{LiCl}+\mathrm{KCl}+\mathrm{LiO})$ systems
}

$\operatorname{AUTHOR}(S):$

Kado, Yuya; Goto, Takuya; Hagiwara, Rika

\section{CITATION:}

Kado, Yuya ... [et al]. Thermodynamics of the $\mathrm{O} / \mathrm{O}^{2}$ redox couple in molten ( $\left.\mathrm{LiCl}+\mathrm{KCl}+\mathrm{LiO}\right)$ systems. The Journal of Chemical Thermodynamics 2010, 42(10): 1230-1233

ISSUE DATE:

2010-10

URL:

http://hdl.handle.net/2433/255614

\section{RIGHT:}

(C) 2010. This manuscript version is made available under the CC-BY-NC-ND 4.0 license http://creativecommons.org/licenses/by-nc-nd/4.0/:; This is not the published version. Please cite only the published version.; この論文は出版社版でありません。引用の際には 出版社版をご確認ご利用ください。 


\title{
Thermodynamics of the $\mathrm{O}_{2} / \mathrm{O}^{2-}$ redox couple in molten $\mathrm{LiCl}-\mathrm{KCl}-\mathrm{Li} 2 \mathrm{O}$ systems
}

\author{
Yuya Kado, Takuya Goto*, Rika Hagiwara \\ Department of Fundamental Energy Science, Graduate School of Energy Science,
}

Kyoto University, Sakyo-ku, Kyoto 606-8501, Japan

*Phone: +81-774-65-6676 Fax : no Fax

Email: tgoto@mail.doshisha.ac.jp 


\begin{abstract}
Activity coefficients of oxide ion were determined by the measurements of the standard formal potential of $\mathrm{O}_{2} / \mathrm{O}^{2-}$ in molten $\mathrm{LiCl}-\mathrm{KCl}$ mixtures; $\mathrm{LiCl}: \mathrm{KCl}=58.5: 41.5$ (eutectic), 65:35, 70:30, 75:25 mol\% at 673 to $803 \mathrm{~K}$. The activity coefficient decreases with the increase of the $\mathrm{LiCl}$ content in the melt; $18.7 \pm 1.5,7.7 \pm 1.0,4.1 \pm 0.4$ and 1.6 \pm 0.1 , respectively, at $773 \mathrm{~K}$ in each melt. The result is explained by the attractive force between $\mathrm{Li}^{+}$and $\mathrm{O}^{2-}$ which is stronger than that between $\mathrm{K}^{+}$and $\mathrm{O}^{2-}$.
\end{abstract}

Keywords: boron-doped diamond electrode; oxygen evolution; activity coefficient 


\section{Introduction}

Oxide ion in the electrolytes is known as a strong Lewis base. It affects the passivation phenomena of metals [1] and plays an important role in acid-base reactions $[2,3]$. In order to understand chemical and electrochemical behavior of oxide ion, it is indispensible to measure the thermodynamic quantities of oxide ion such as chemical potentials in molten chlorides. Some researchers previously reported on the oxygen electrode reaction in molten chlorides [3-7], however, these results did not coincide with each other, which was attributed to the fact that an ideally polarizable electrode (IPE) under oxygen atmosphere at high temperatures was not available.

On the other hand, in our previous study, a boron-doped diamond (BDD) electrode was found to act as an oxygen gas evolution electrode in molten chloride systems below $773 \mathrm{~K}[8-10]$.

$$
\mathrm{O}^{2-} \rightarrow \frac{1}{2} \mathrm{O}_{2}+2 \mathrm{e}^{-}
$$

In addition, thermodynamic investigations on the oxygen electrode reaction revealed that the BDD electrode acts as an IPE under oxygen atmosphere in a $\mathrm{LiCl}-\mathrm{KCl}$ eutectic melt containing oxide ion [11]. The standard formal potential of $\mathrm{O}_{2} / \mathrm{O}^{2-}, E_{\mathrm{O}_{2} / \mathrm{O}^{2-}}^{0^{\prime}}$, defined by eq. 2 is $2.995( \pm 0.001)-7.38( \pm 0.14) \times 10^{-4} T$ vs. $\mathrm{Li}^{+} / \mathrm{Li}$ in the temperature range of 673 to $803 \mathrm{~K}$. 


$$
E_{\mathrm{O}_{2} / \mathrm{O}^{2-}}^{0^{\prime}}=E_{\mathrm{O}_{2} / \mathrm{O}^{2-}}^{0}+\frac{R T}{2 F} \ln \frac{\gamma_{\mathrm{O}_{2}}^{1 / 2}}{\gamma_{\mathrm{O}^{2-}}}
$$

Here, $E_{\mathrm{O}_{2} / \mathrm{O}^{2-}}^{0}$ is the standard potential of $\mathrm{O}_{2} / \mathrm{O}^{2-}, R$; the gas constant, $T$; absolute temperature, $F$; the Faraday constant, $\gamma_{\mathrm{O}_{2}}$; the fugacity coefficient of $\mathrm{O}_{2}$ and $\gamma_{\mathrm{O}^{2-}}$; the activity coefficient of the $\mathrm{O}^{2-}$. In the present study, further investigations on the oxygen electrode reaction were carried out in various compositions of $\mathrm{LiCl}-\mathrm{KCl}$ mixtures. The relationship between the standard formal potential of $\mathrm{O}_{2} / \mathrm{O}^{2-}$ and the melt compositions was evaluated and activity coefficients of oxide ion were determined from the obtained data.

\section{Experimental}

Reagent-grade LiCl (Aldrich-APL $99.99 \%$ ) and $\mathrm{KCl}$ (Aldrich-APL $99.99 \%$ ) were mixed to prepare each composition $(\mathrm{LiCl}: \mathrm{KCl}=58.5: 41.5,65: 35,70: 30,75: 25$ mol\%) and used for the melts in a high purity alumina crucibles (SSA-S, NIKKATO) after vacuum drying at $573 \mathrm{~K}$ for 24 hours. $\mathrm{Li}_{2} \mathrm{O}$ (Aldrich. $97 \%$ ) was used as an oxide ion source which was directly added into the melts after vacuum drying at $453 \mathrm{~K}$ for 24 hours. All the experiments were performed in a glove box with a gas-refining instrument (MIWA, MS3-H60SN) under dried and deoxygenated atmosphere. The concentration of water and oxygen gas in the atmosphere were always monitored and 
kept less than 1 ppm. A BDD electrode (Sumitomo Electric Industries, Ltd., thickness: $20 \mu \mathrm{m}$, substrate: silicon, doped boron: 500-3000 ppm) was used as a working electrode. The $\mathrm{Ag}^{+} / \mathrm{Ag}$ reference electrode was prepared by immersing a silver wire (Japan Metal Service, $99.99 \%$ ) was in the melt containing $0.5 \mathrm{~mol} \% \mathrm{AgCl}$ (Wako Pure Chemical Co. Ltd., $99.5 \%)$ in a Pyrex glass tube with a thin bottom. The potential of the reference electrode was standardized against the potential of $\mathrm{Li}^{+} / \mathrm{Li}$. Electrochemical measurements were performed with the aid of an electrochemical measurement system (Hokuto Denko Corp., HZ-5000).

\section{Results and discussion}

\subsection{Standard formal potential of $\mathrm{O}_{2} / \mathrm{O}^{2-}$}

The standard formal potential of $\mathrm{O}_{2} / \mathrm{O}^{2-}$ was measured by our method using the BDD electrode in LiCl-KCl mixtures; $\mathrm{LiCl}: \mathrm{KCl}=65: 35,70: 30$ and 75:25 mol\% containing $0.5 \mathrm{~mol} \% \mathrm{Li}_{2} \mathrm{O}$ as shown in Fig. 1. The result in the eutectic melt is also included as a reference [11]. In each melt, the standard formal potential of $\mathrm{O}_{2} / \mathrm{O}^{2-}$ decreases almost linearly with the elevation of temperature. The temperature dependences of the standard formal potentials are summarized in Table 1. In addition, it 
is found that the potential is more positive in the melt which has a larger content of $\mathrm{LiCl}$.

Here, these potentials are referenced to the standard potential of the $\mathrm{Li}^{+} / \mathrm{Li}$ redox couple regarding the activity of $\mathrm{Li}^{+}$as follows. The potential of $\mathrm{Li}^{+} / \mathrm{Li}$ is expressed as;

$$
E_{\mathrm{Li}^{+} / \mathrm{Li}}=E_{\mathrm{Li}^{+} / \mathrm{Li}}^{0}+\frac{R T}{F} \ln a_{\mathrm{Li}^{+}}
$$

where $E_{\mathrm{Li}^{+} / \mathrm{Li}}^{0}$ is the standard potential of $\mathrm{Li}^{+} / \mathrm{Li}$ and $a_{\mathrm{Li}^{+}}$is the activity of $\mathrm{Li}^{+}$. Since $E_{\mathrm{Li}^{+} / \mathrm{Li}}$ was defined to be zero in each melt, $E_{\mathrm{Li}^{+} / \mathrm{Li}}^{0}$ is expressed as follows.

$$
E_{\mathrm{Li}^{+} / \mathrm{Li}}^{0}=-\frac{R T}{F} \ln \left(\gamma_{\mathrm{Li}^{+}} X_{\mathrm{Li}^{+}}\right)
$$

Here, $\gamma_{\mathrm{Li}^{+}}$is the activity coefficient and $X_{\mathrm{Li}^{+}}$is the cation fraction of $\mathrm{Li}^{+}$in the melt.

The standard potential of $\mathrm{Li}^{+} / \mathrm{Li}$ is calculated using the following relation between the activity coefficient of $\mathrm{Li}^{+}$and the cation fraction in molten $\mathrm{LiCl}-\mathrm{KCl}$ [12].

$$
R T \ln \gamma_{\mathrm{Li}^{+}}=-13390\left(1-X_{\mathrm{Li}^{+}}\right)^{2}
$$

Thus, the standard formal potential of $\mathrm{O}_{2} / \mathrm{O}^{2-}, E_{\mathrm{O}_{2} / \mathrm{O}^{2-}}^{0^{\prime}}$, against the potential of $\mathrm{Li}^{+} / \mathrm{Li}$ in each melt obtained in the present study is calculated to be the normalized value against the standard potential of $\mathrm{Li}^{+} / \mathrm{Li}, E_{\mathrm{Li}^{+} / \mathrm{Li}}^{0}$, from eq. 6 .

$$
E_{\mathrm{O}_{2} / \mathrm{O}^{2-}}^{0^{\prime}}\left(\text { vs. } E_{\mathrm{Li}^{+} / \mathrm{Li}}^{0}\right)=E_{\mathrm{O}_{2} / \mathrm{O}^{2-}}^{0^{\prime}}-E_{\mathrm{Li}^{+} / \mathrm{Li}}^{0}
$$

\subsection{Change of free energy, entropy, enthalpy}

The standard free energy change for the reaction (7) is given by eq. 8 [11]. 


$$
\begin{aligned}
& 2 \mathrm{Li}(\mathrm{l})+\frac{1}{2} \mathrm{O}_{2}(\mathrm{~g})=2 \mathrm{Li}^{+}+\mathrm{O}^{2-} \\
& \Delta G^{0^{\prime}}(7)=-2 F\left(E_{\mathrm{O}_{2} / \mathrm{O}^{2-}}^{0^{\prime}}-E_{\mathrm{Li}^{+} / \mathrm{Li}}^{0}\right)
\end{aligned}
$$

The free energy change almost linearly increases with the elevation of temperature as shown in Fig. 2. In addition, it decreases with the increase of the $\mathrm{LiCl}$ content in the melt; $-456.4 \pm 0.5,-462.1 \pm 0.8,-466.1 \pm 0.6$ and $-472.1 \pm 0.5$, respectively, at 773 $\mathrm{K}$ in each melt, indicating the reaction (7) is more favorable to proceed to the right direction in the melt with a larger content of $\mathrm{LiCl}$.

The standard formal entropy change, $\Delta S^{0^{\prime}}(7)$, and the standard formal enthalpy change, $\Delta H^{0^{\prime}}(7)$, are also calculated according to eqs. 9 and 10.

$$
\begin{aligned}
& \Delta S^{0^{\prime}}(7)=-\left(\frac{\partial \Delta G^{0^{\prime}}(7)}{\partial T}\right)_{p} \\
& \Delta H^{0^{\prime}}(7)=\Delta G^{0^{\prime}}(7)+T \Delta S^{0^{\prime}}(7)
\end{aligned}
$$

The obtained standard formal entropy and enthalpy are summarized in Table 2. $\Delta S^{0^{\prime}}(7)$ and $\Delta H^{0^{\prime}}(7)$ are practically constant in these temperature ranges. These values are plotted against the cation fraction of $\mathrm{Li}^{+}$in Figs. 3 and 4. $\Delta S^{0^{\prime}}$ (7) increases and $\Delta H^{0^{\prime}}$ (7) decreases with the increase of the cation fraction of $\mathrm{Li}^{+} \cdot \Delta S^{0^{\prime}}(7)$ and $\Delta H^{0^{\prime}}(7)$ in a $\mathrm{LiCl}$ single salt $\left(X_{\mathrm{Li}^{+}}=1\right)$ are estimated to be $-115 \pm 6 \mathrm{~J} \mathrm{~K}^{-1} \mathrm{~mol}^{-1}$ and $-584.8 \pm 0.1$ $\mathrm{kJ} \mathrm{mol}^{-1}$, respectively by the extrapolation of the obtained data. The standard formal free energy change and the standard formal potential of $\mathrm{O}_{2} / \mathrm{O}^{2-}$ are given by eqs. 11 and 
12.

$$
\begin{aligned}
& \Delta G^{0^{\prime}}(7)=116( \pm 6) \times 10^{-3} T-584.8( \pm 0.1) / \mathrm{kJ} \mathrm{mol}^{-1} \\
& E_{\mathrm{O}_{2} / \mathrm{O}^{2-}}^{0^{\prime}}=3.031( \pm 0.001)-5.96( \pm 0.31) \times 10^{-4} T / \mathrm{V} \text { vs. } \mathrm{Li}^{+} / \mathrm{Li}
\end{aligned}
$$

At $923 \mathrm{~K}$, which is the typical temperature for the reduction of uranium oxides in a $\mathrm{LiCl}$ single salt, they are respectively $-477.7 \pm 5.4 \mathrm{~kJ} \mathrm{~mol}^{-1}$ and $-2.474 \pm 0.028 \mathrm{~V} \mathrm{vs.} \mathrm{Li}^{+} / \mathrm{Li}$. From this result, the EMF for the electrochemical reduction of uranium oxides expressed by the reaction (13) is calculated to be $0.13 \pm 0.03 \mathrm{~V} \mathrm{vs.} \mathrm{Li}^{+} / \mathrm{Li}$ in a $\mathrm{LiCl}$ melt containing $0.52 \mathrm{~mol} \% \mathrm{Li}_{2} \mathrm{O}$.

$$
\mathrm{UO}_{2}(\mathrm{~s})+4 \mathrm{e}^{-}=\mathrm{U}(\mathrm{s})+2 \mathrm{O}^{2-}
$$

This value is estimated from the standard formal potential of $\mathrm{O}_{2} / \mathrm{O}^{2-}$ obtained in the present study and the standard potential of $\mathrm{U}^{4+} / \mathrm{U}$ calculated from the standard Gibbs free energy of formation of solid $\mathrm{UO}_{2}$ for the reaction (15) [13], corresponding to the potential of the redox couple of $\mathrm{O}_{2} / \mathrm{O}^{2-}$ estimated from the polarization curve in the previous report by Sakamura et al. [14].

$$
\begin{aligned}
& \frac{1}{2} \mathrm{O}_{2}+2 \mathrm{e}^{-}=\mathrm{O}^{2-} \\
& \mathrm{U}(\mathrm{s})+\mathrm{O}_{2}(\mathrm{~g})=\mathrm{UO}_{2}(\mathrm{~s})
\end{aligned}
$$

\subsection{Activity coefficients of oxide ion}


The obtained formal thermodynamic quantities are compared with the literature data for formation of liquid $\mathrm{Li}_{2} \mathrm{O}$ from liquid $\mathrm{Li}$ and gaseous $\mathrm{O}_{2}[13,15]$.

$$
\begin{aligned}
& 2 \mathrm{Li}(\mathrm{l})+\frac{1}{2} \mathrm{O}_{2}(\mathrm{~g})=\mathrm{Li}_{2} \mathrm{O}(\mathrm{l}) \\
& 2 \mathrm{Li}(\mathrm{l})+\frac{1}{2} \mathrm{O}_{2}(\mathrm{~g})=2 \mathrm{Li}^{+}+\mathrm{O}^{2-}
\end{aligned}
$$

When the standard state is defined to be pure $\mathrm{Li}_{2} \mathrm{O}$ liquid, the standard free energy of formation of $\mathrm{Li}_{2} \mathrm{O}$ (1), $\Delta G_{\mathrm{f}}^{0}$ (liquid $\mathrm{Li}_{2} \mathrm{O}$ ), corresponds to the standard free energy change of the reaction (7), $\Delta G^{0}$ (7). Therefore, the difference between $\Delta G_{\mathrm{f}}^{0}$ (liquid $\mathrm{Li}_{2} \mathrm{O}$ ) and $\Delta G^{0^{\prime}}(7)$ is expressed by the activity coefficient of $\mathrm{O}_{2}, \gamma_{\mathrm{O}_{2}}$, and $\mathrm{O}^{2-}, \gamma_{\mathrm{O}^{2-}}$, using the relation given by eq. 18 .

$$
\begin{aligned}
& \Delta G(7)=\Delta G^{0}(7)+R T \ln \frac{\gamma_{\mathrm{O}_{2}}^{1 / 2}}{\gamma_{\mathrm{O}^{2-}}}+R T \ln \frac{P_{\mathrm{O}_{2}}^{1 / 2}}{X_{\mathrm{O}^{2-}}} \\
& \Delta G^{0}(7)=\Delta G^{0^{1}}(7)+R T \ln \frac{\gamma_{\mathrm{O}_{2}}^{1 / 2}}{\gamma_{\mathrm{O}^{2-}}}
\end{aligned}
$$

Here, activity coefficient of oxygen gas can be regarded as unity because only oxygen gas is used as a gas phase and it does not depend on oxygen pressures [11]. Therefore $\gamma_{\mathrm{O}^{2-}}$ in the dilute $\mathrm{O}^{2-}$ region is estimated as shown in Fig. 5. The activity coefficient decreases with the increase of the $\mathrm{LiCl}$ content in the melt and depends more strongly on the melt composition than on the temperature. It is considered that the attractive force between $\mathrm{Li}^{+}$and $\mathrm{O}^{2-}$ ion is stronger than that between $\mathrm{K}^{+}$and $\mathrm{O}^{2-}$ affecting the 
acitivity of oxide ions in the melt. In a $\mathrm{LiCl}$ melt which is a typical system for the reduction of uranium oxides, the activity coefficient of $\mathrm{O}^{2-}$ is estimated to be $0.07 \pm 0.05$. The result is explained by the repulsive force between $\mathrm{O}^{2-}$ and $\mathrm{Cl}^{-}$which is weaker than that between the two $\mathrm{O}^{2-}$.

\section{Conclusion}

Standard formal potentials of $\mathrm{O}_{2} / \mathrm{O}^{2-}$ were measured using the $\mathrm{BDD}$ electrode as an IPE and activity coefficients of oxide ion were determined in molten $\mathrm{LiCl}-\mathrm{KCl}$ mixtures; $\mathrm{LiCl}: \mathrm{KCl}=58.5: 41.5$ (eutectic), 65:35, 70:30 and 75:25 mol\% containing 0.5 $\mathrm{mol} \% \mathrm{Li}_{2} \mathrm{O}$ at 673 to $803 \mathrm{~K}$. The standard formal potential of $\mathrm{O}_{2} / \mathrm{O}^{2-}$ is more positive in the melt which has a larger content of $\mathrm{LiCl}$ and the activity coefficient of oxide ion decreases with the increase of the $\mathrm{LiCl}$ content in the melt. From these results, in a $\mathrm{LiCl}$ melt at $923 \mathrm{~K}$ which is a typical system for the reduction of uranium oxides, the standard formal potential and the activity coefficient are estimated by extrapolation to be $E_{\mathrm{O}_{2} / \mathrm{O}^{2-}}^{0^{\prime}}=-2.474 \pm 0.028 \mathrm{~V}$ vs. $\mathrm{Li}^{+} / \mathrm{Li}$ and $0.07 \pm 0.05$, respectively. Thus, this study has given available data for thermodynamic consideration on chemical and electrochemical processes involving oxygen gas and/or oxide ion such as reduction 
processes of metal oxides in molten $\mathrm{LiCl}-\mathrm{KCl}$ systems. 


\section{References}

[1] X. K. Feng and C. A. Melendres, J. Electrochem. Soc., 129, 1245 (1982).

[2] R. Littlewood, J. Electrochem. Soc., 109, 525 (1962).

[3] N. Masuko, M. Okada and T. Hisamatsu, Yoyuen, 6, 570, (1963).

[4] V. L. Cherginets, O. V. Demirskaya and T. P. Rebrova, F. Chem. Thermodynamics, 36,115 (2004).

[5] V. L. Cherginets, Electrochim. Acta, 42, 1507 (1997).

[6] N. S. Wrench and D. Inman, J. Electroanal.Chem., 17319 (1968).

[7] Y. Kanzaki and M. Takahashi, J. Electroanal. Chem., 58, 339 (1975).

[8] T. Goto, Y. Araki and R. Hagiwara, Electrochem. Solid-State Lett., 9, D5 (2006).

[9] Y. Kado, T. Goto and R. Hagiwara, J. Electrochem. Soc., 155, E85 (2008).

[10] Y. Kado, T. Goto and R. Hagiwara, Diamond and Related Materials, 18, 1186 (2009).

[11] Y. Kado, T. Goto and R. Hagiwara, J. Electrochem. Soc., 156 (11), E167 (2009).

[12] J. Lumsden, Thermodynamics of Molten Salt Mixtures, p.47, Academic Press, London (1966).

[13] Landolt-Börnstein, Thermodynamic Properties of Inorganic Material, SGTE, Springer- Verlag, Berlin-Heidelberg (2001) 
[14] Y. Sakamura, M. Kurata and T. Inoue, J. Electrochem. Soc., 153, D31 (2006).

[15] Glushko Thermocenter of the Russian Academy of Sciences, IVTAN Association,

Izhorskaya 13/19, 127412 Moscow, Russia (1994). 


\section{List of table and figure captions}

Table 1 The standard formal potential of $\mathrm{O}_{2} / \mathrm{O}^{2-}$ against the standard potential of $\mathrm{Li}^{+} / \mathrm{Li}^{2}$ in molten $\mathrm{LiCl}-\mathrm{KCl}$ mixtures; $\mathrm{LiCl}: \mathrm{KCl}=$ 58.5:41.5 (eutectic), 65:35, 70:30 and 75:25 mol\% containing $0.5 \mathrm{~mol} \% \mathrm{Li}_{2} \mathrm{O}$. (The error values denote the $95 \%$ confidence intervals.)

Table 2 Thermodynamic data (a) obtained in this study and (b) calculated data from the solubility of $\mathrm{Li}_{2} \mathrm{O}$ for the reaction (7): $2 \mathrm{Li}+1 / 2 \mathrm{O}_{2}=2 \mathrm{Li}^{+}+\mathrm{O}^{2-}$ (The error values denote the $95 \%$ confidence intervals.)

Fig. 1 Temperature dependence of the standard formal potential of $\mathrm{O}_{2} / \mathrm{O}^{2-}$ vs. the standard formal potential of $\mathrm{Li}^{+} / \mathrm{Li}$ in molten $\mathrm{LiCl}-\mathrm{KCl}$ mixtures; $\mathrm{LiCl}: \mathrm{KCl}=$ (a) 58.5:41.5 (eutectic), (b) 65:35, (c) 70:30 (d) 75:25 mol\% containing 0.5 mol\% $\mathrm{Li}_{2} \mathrm{O}$. (The error values denote the $95 \%$ confidence intervals.)

Fig. 2 Temperature dependence of the standard free energy change for the reaction (7): $2 \mathrm{Li}+1 / 2 \mathrm{O}_{2}=2 \mathrm{Li}^{+}+\mathrm{O}^{2-}$ in molten LiCl-KCl mixtures; $\mathrm{LiCl}: \mathrm{KCl}=$ (a) $58.5: 41.5$ (eutectic), (b) $65: 35$, (c) 70:30 (d) 75:25 mol\% containing $0.5 \mathrm{~mol} \% \mathrm{Li}_{2} \mathrm{O}$. (The error values denote the $95 \%$ confidence intervals.)

Fig. 3 Relationship between the cation fraction of $\mathrm{Li}^{+}$and the standard formal entropy 
change for the reaction (7): $2 \mathrm{Li}+1 / 2 \mathrm{O}_{2}=2 \mathrm{Li}^{+}+\mathrm{O}^{2-}$ in molten $\mathrm{LiCl}-\mathrm{KCl}$ mixtures; $\mathrm{LiCl}: \mathrm{KCl}=58.5: 41.5$ (eutectic), 65:35, 70:30 and 75:25 mol\% containing $0.5 \mathrm{~mol} \%$ $\mathrm{Li}_{2} \mathrm{O}$. (The error values denote the $95 \%$ confidence intervals.)

Fig. 4 Relationship between the cation fraction of $\mathrm{Li}^{+}$and the standard formal enthalpy change for the reaction (6): $2 \mathrm{Li}+1 / 2 \mathrm{O}_{2}=2 \mathrm{Li}^{+}+\mathrm{O}^{2-}$ in molten $\mathrm{LiCl}-\mathrm{KCl}$ mixtures; $\mathrm{LiCl}: \mathrm{KCl}=58.5: 41.5$ (eutectic), 65:35, 70:30 and 75:25 mol\% containing $0.5 \mathrm{~mol} \%$ $\mathrm{Li}_{2} \mathrm{O}$. (The error values denote the $95 \%$ confidence intervals.

Fig. 5 Activity coefficients of $\mathrm{O}^{2-}$ ion in molten LiCl-KCl mixtures; $\mathrm{LiCl}: \mathrm{KCl}=$ 58.5:41.5 (eutectic), 65:35, 70:30 and 75:25 mol\% containing 0.5 mol\% $\mathrm{Li}_{2} \mathrm{O}$. (The error values denote the $95 \%$ confidence intervals.) 
Table 1 The standard formal potential of $\mathrm{O}_{2} / \mathrm{O}^{2-}$ against the standard potential of $\mathrm{Li}^{+} / \mathrm{Li}$ in molten $\mathrm{LiCl}-\mathrm{KCl}$ mixtures; $\mathrm{LiCl}: \mathrm{KCl}=58.5: 41.5$ (eutectic), 65:35, 70:30 and 75:25 mol\% containing $0.5 \mathrm{~mol} \% \mathrm{Li}_{2} \mathrm{O}$. (The error values denote the $95 \%$ confidence intervals.)

$$
E_{\mathrm{O}_{2} / \mathrm{O}^{2}}^{0^{\prime}}=a-b T \text { vs. } E_{\mathrm{Li}^{+} / \mathrm{Li}}^{0}
$$

\begin{tabular}{|c|c|c|c|}
\hline $\mathrm{LiCl}: \mathrm{KCl} / \mathrm{mol} \%$ & Temperature / K & $a$ & $b$ \\
\hline $58.5: 41.5$ (Ref. 11) & $673-803$ & $2.972 \pm 0.001$ & $7.84 \pm 0.13$ \\
\hline $65: 35$ & $723-803$ & $2.976 \pm 0.001$ & $7.52 \pm 0.27$ \\
\hline $70: 30$ & $723-803$ & $2.987 \pm 0.001$ & $7.38 \pm 0.29$ \\
\hline $75: 25$ & $773-803$ & $2.995 \pm 0.001$ & $7.10 \pm 0.47$ \\
\hline
\end{tabular}


Table 2 Thermodynamic data (a) obtained in this study and (b) calculated data from the solubility of $\mathrm{Li}_{2} \mathrm{O}$ for the reaction (7): $2 \mathrm{Li}+1 / 2 \mathrm{O}_{2}=2 \mathrm{Li}^{+}+\mathrm{O}^{2-}$ (The error values denote the $95 \%$ confidence intervals.)

\begin{tabular}{cccc}
\hline $\mathrm{LiCl}: \mathrm{KCl}$ & $T / \mathrm{K}$ & $\Delta S^{0^{\prime}}(7) / \mathrm{J} \mathrm{K}^{-1} \mathrm{~mol}^{-1}$ & $\Delta H^{0^{\prime}}(7) / \mathrm{kJ} \mathrm{mol}^{-1}$ \\
\hline $58.5: 41.5$ & $673-803$ & $-151 \pm 3$ & $-573.5 \pm 0.1$ \\
$65: 35$ & $723-803$ & $-145 \pm 5$ & $-574.2 \pm 0.1$ \\
$70: 30$ & $723-803$ & $-142 \pm 6$ & $-576.4 \pm 0.2$ \\
$75: 25$ & $773-803$ & $-137 \pm 8$ & $-578.0 \pm 0.1$ \\
\hline
\end{tabular}




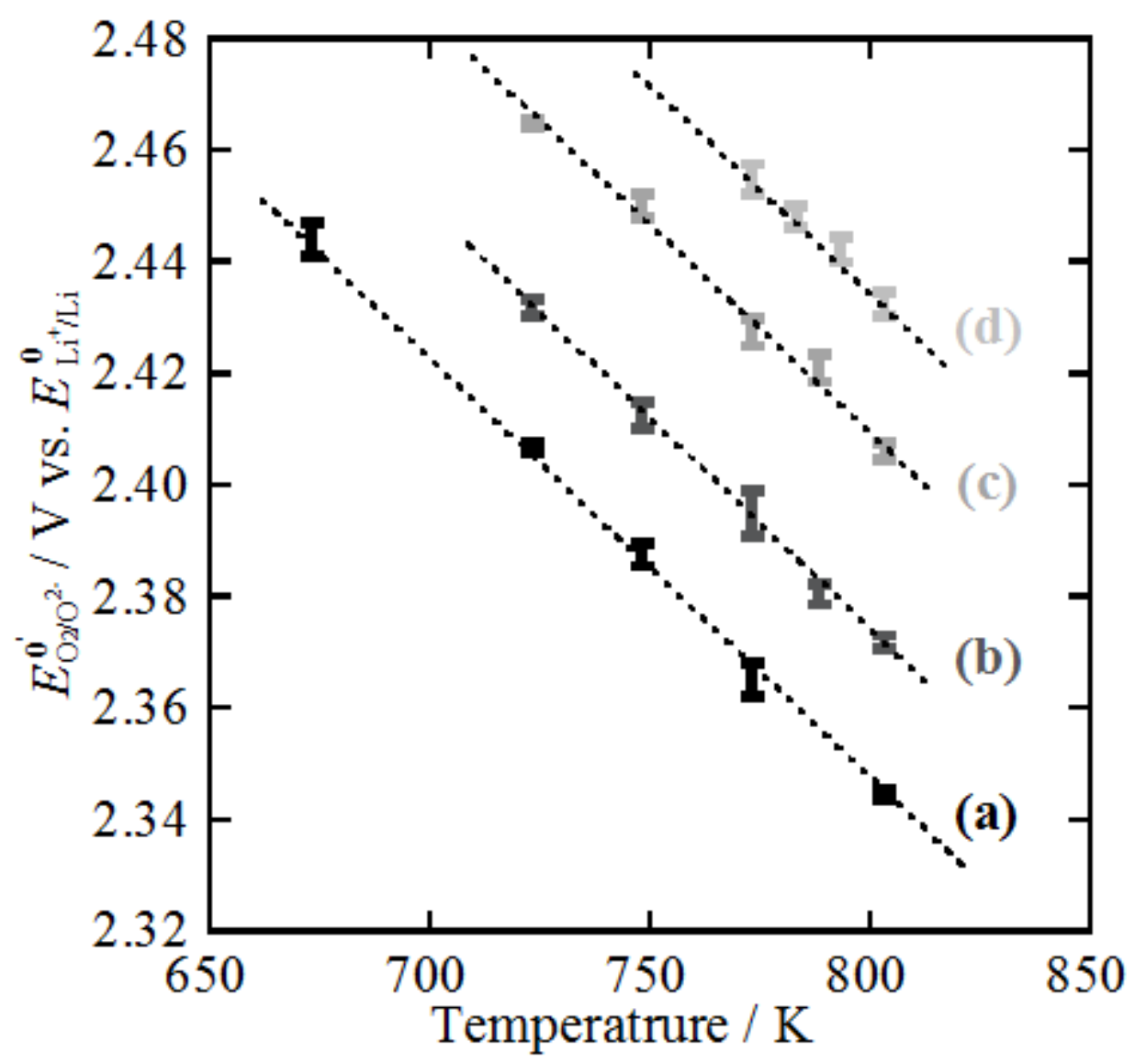

Fig. 1 Temperature dependence of the standard formal potential of $\mathrm{O}_{2} / \mathrm{O}^{2-}$ vs. the standard formal potential of $\mathrm{Li}^{+} / \mathrm{Li}$ in molten $\mathrm{LiCl}-\mathrm{KCl}$ mixtures; $\mathrm{LiCl}: \mathrm{KCl}=$ (a) 58.5:41.5 (eutectic), (b) 65:35, (c) 70:30 (d) 75:25 mol\% containing $0.5 \mathrm{~mol} \% \mathrm{Li}_{2} \mathrm{O}$. (The error values denote the $95 \%$ confidence intervals.) 


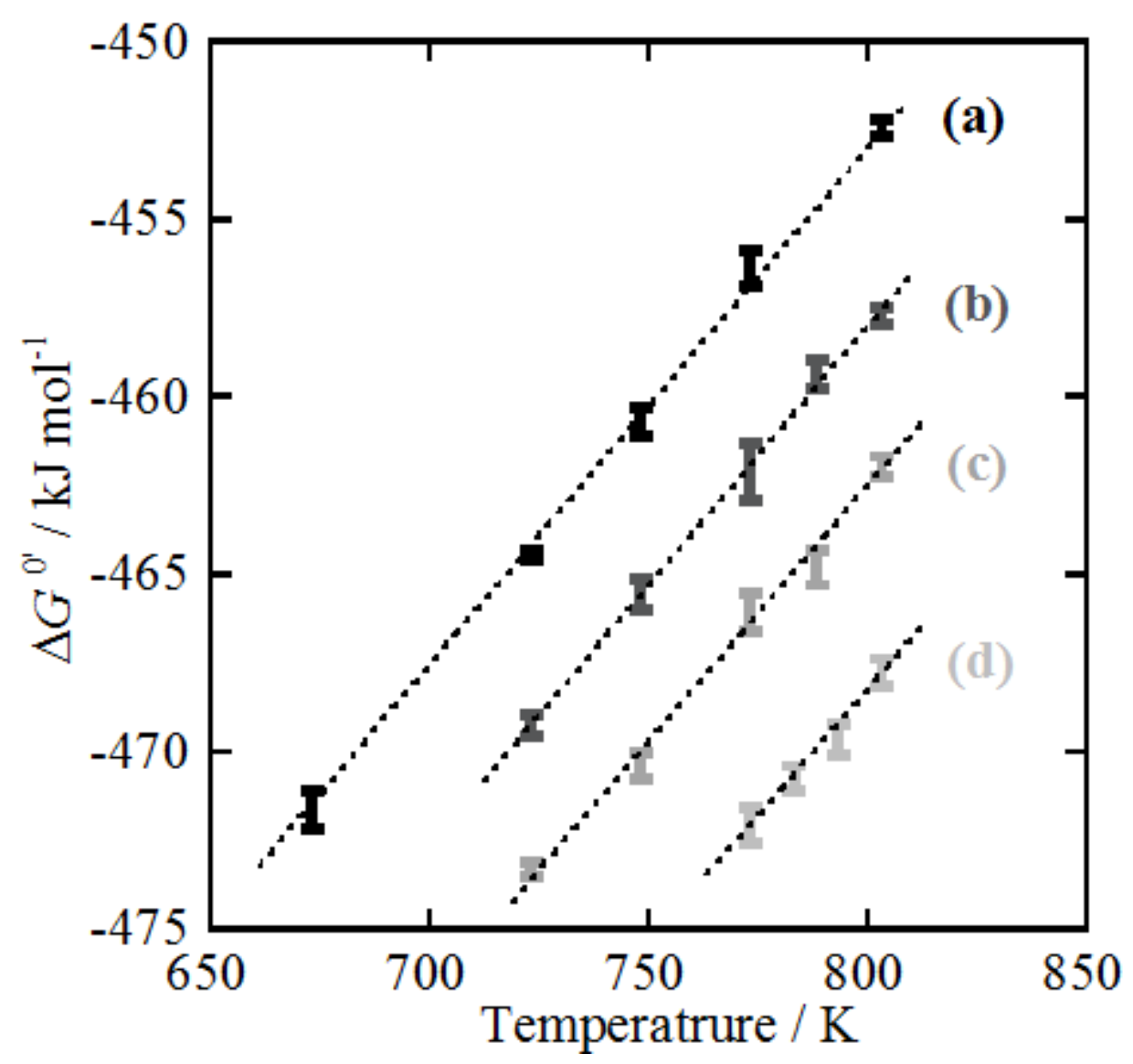

Fig. 2 Temperature dependence of the standard free energy change for the reaction (7):

$2 \mathrm{Li}+1 / 2 \mathrm{O}_{2}=2 \mathrm{Li}^{+}+\mathrm{O}^{2-}$ in molten LiCl-KCl mixtures; $\mathrm{LiCl}: \mathrm{KCl}=$ (a) $58.5: 41.5$ (eutectic), (b) $65: 35$, (c) 70:30 (d) 75:25 mol\% containing $0.5 \mathrm{~mol} \% \mathrm{Li}_{2} \mathrm{O}$. (The error values denote the $95 \%$ confidence intervals.) 


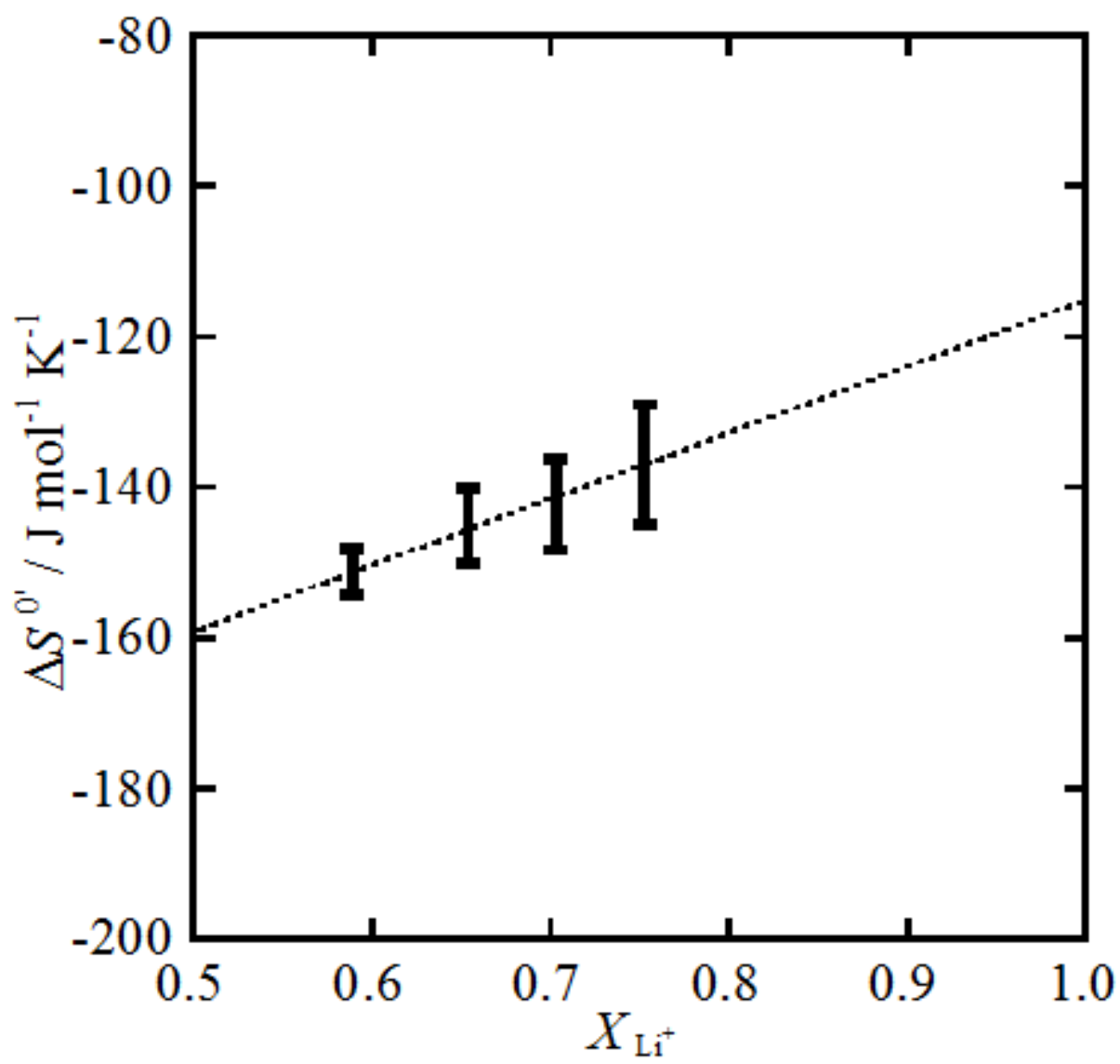

Fig. 3 Relationship between the cation fraction of $\mathrm{Li}^{+}$and the standard formal entropy change for the reaction (7): $2 \mathrm{Li}+1 / 2 \mathrm{O}_{2}=2 \mathrm{Li}^{+}+\mathrm{O}^{2-}$ in molten $\mathrm{LiCl}-\mathrm{KCl}$ mixtures; $\mathrm{LiCl}: \mathrm{KCl}=58.5: 41.5$ (eutectic), 65:35, 70:30 and 75:25 mol\% containing $0.5 \mathrm{~mol} \%$ $\mathrm{Li}_{2} \mathrm{O}$. (The error values denote the $95 \%$ confidence intervals.) 


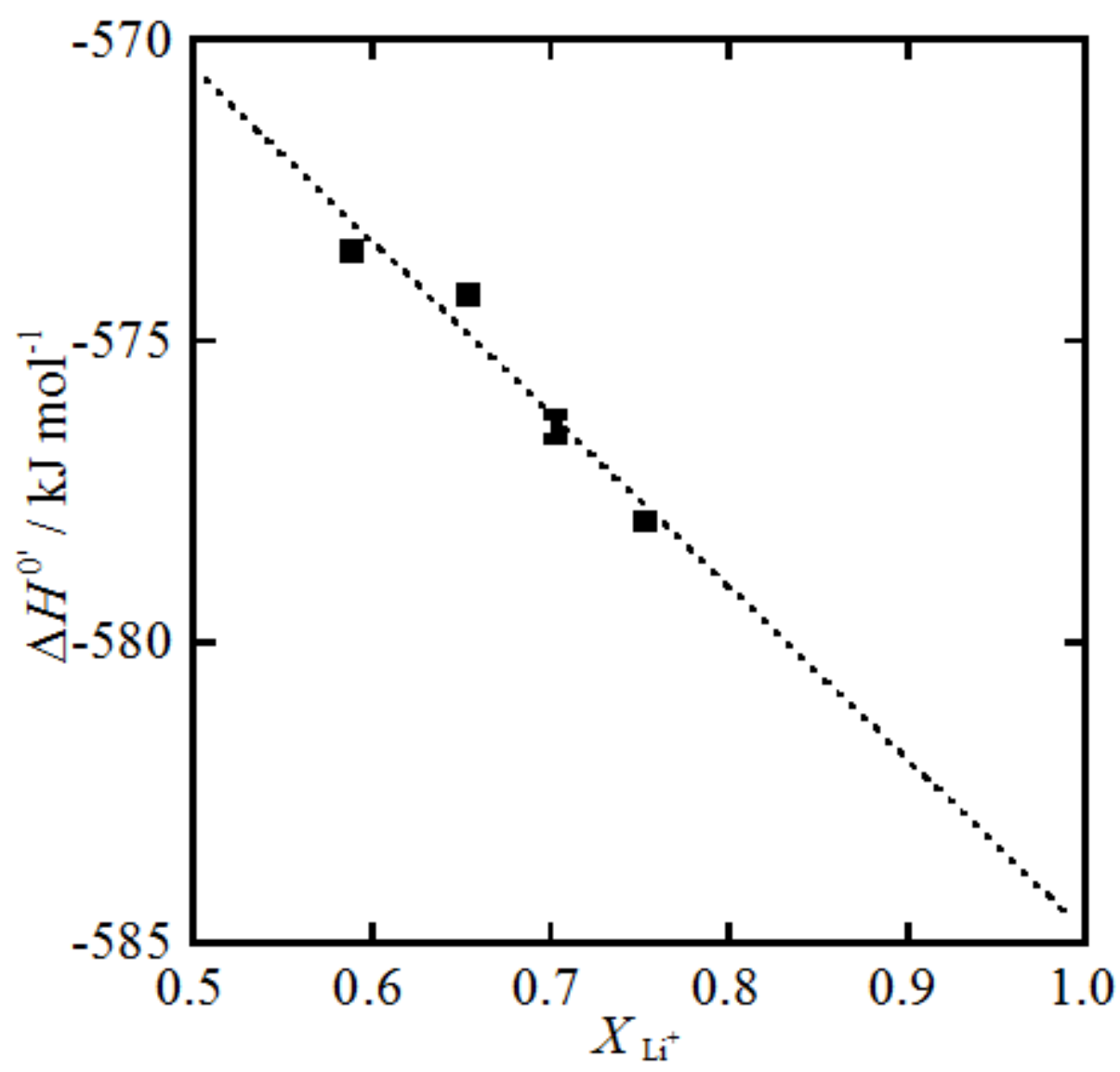

Fig. 4 Relationship between the cation fraction of $\mathrm{Li}^{+}$and the standard formal enthalpy change for the reaction (7): $2 \mathrm{Li}+1 / 2 \mathrm{O}_{2}=2 \mathrm{Li}^{+}+\mathrm{O}^{2-}$ in molten $\mathrm{LiCl}-\mathrm{KCl}$ mixtures; $\mathrm{LiCl}: \mathrm{KCl}=58.5: 41.5$ (eutectic), 65:35, 70:30 and 75:25 mol\% containing $0.5 \mathrm{~mol} \%$ $\mathrm{Li}_{2} \mathrm{O}$. (The error values denote the $95 \%$ confidence intervals.) 


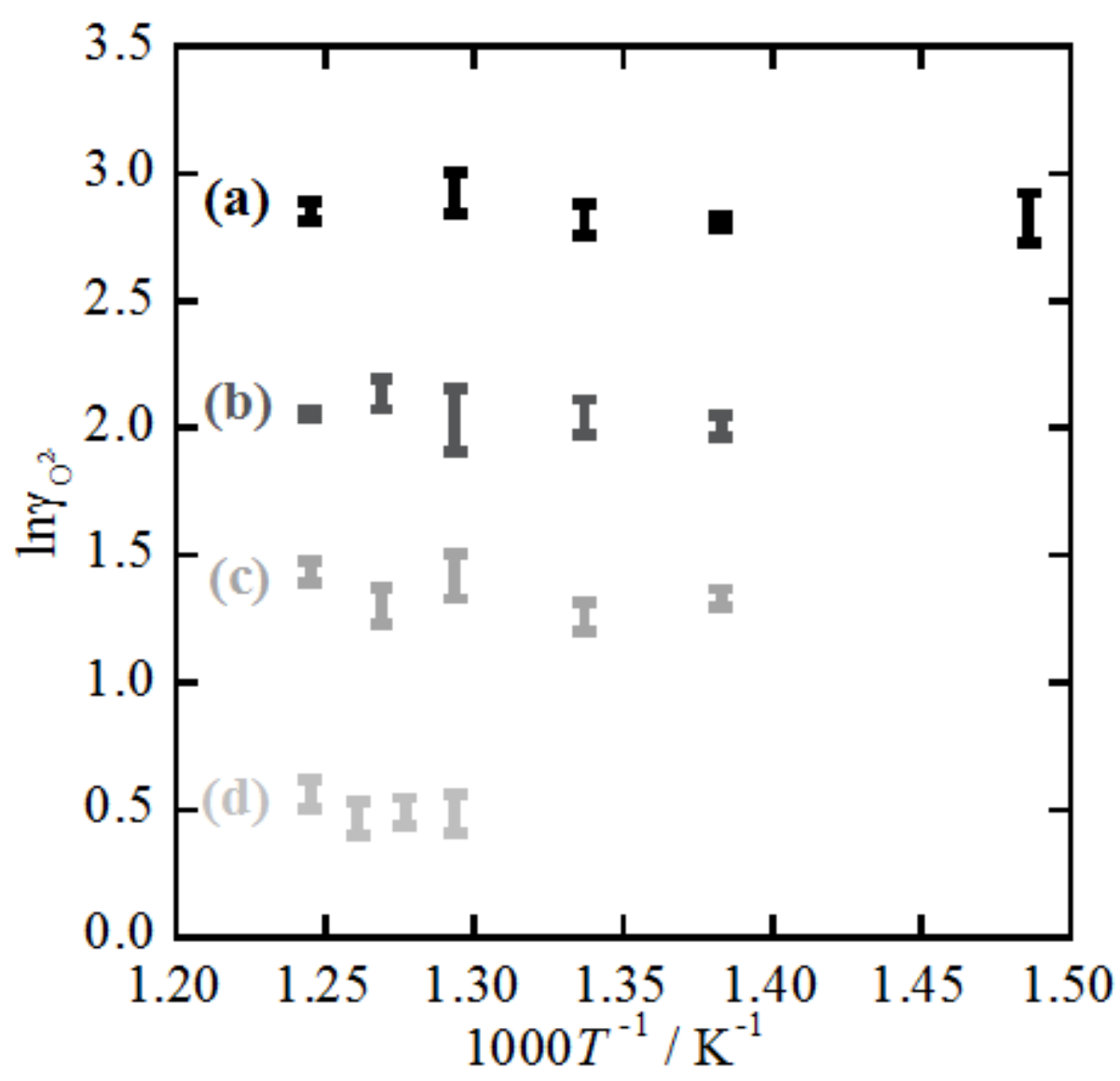

Fig. 5 Activity coefficients of $\mathrm{O}^{2-}$ ion in molten LiCl-KCl mixtures; $\mathrm{LiCl}: \mathrm{KCl}=$ 58.5:41.5 (eutectic), 65:35, 70:30 and 75:25 mol\% containing $0.5 \mathrm{~mol} \% \mathrm{Li}_{2} \mathrm{O}$. (The error values denote the $95 \%$ confidence intervals.) 